ISCKMC 2020

International Scientific Congress «KNOWLEDGE, MAN AND CIVILIZATION»

\title{
FAMILY VALUES OF MODERN ORTHODOXY (BASED ON MARRIAGE ANNOUNCEMENTS)
}

\author{
Tatiana Itskovich (a)* \\ *Corresponding author
}

(a) Department of Russian Language, General Linguistics and Speech Communication, Department of the "Philological Faculty", Ural Federal University named after the first President of Russia B.N. Yeltsin, 51, Lenin str., Yekaterinburg, Russia, tatiana.itckovich@urfu.ru

\begin{abstract}
The study of value attitudes is a relevant direction of modern humanitarian research, including linguistics. Value attitudes are manifested in family life that is relevant to the individual. Value attitudes are influenced by axiological ideals; in Orthodoxy, it is a prototext of the Holy Scriptures. Axiological ideals and reality are in dichotomous relationships. The purpose of the article is to describe the axiological reality of family. The material used for research is male and female marriage announcements posted on Orthodox dating sites. The Internet space is distinguished by freedom of expression. It can be assumed that texts of Orthodox marriage announcements explicate value-oriented attitudes interiorized by the individual, demonstrating the current state of axiological reality. The values reflected in male and female Orthodox marriage announcements are determined by the religious worldview of authors. Values of the Soviet period are verbalized, and there are no modern hedonistic values. The texts of Orthodox marriage announcements reflect the axiological reality of family relations based on the axiological ideals: faith in God, decency, chastity, innocence, kindness and absence of commercial interests. The values formed in the Soviet society have been preserved.
\end{abstract}




\section{Introduction}

The study of ways of verbalizing values in language is one of the topical areas of linguistic research (Vepreva et al., 2016; Vepreva et al., 2018). Value attitudes are manifested in the personal, family sphere (Vepreva, 2018).

Family values declared as a spiritual constant that holds together modern Russian society have relied on religious principles since the 90 s of the XX century. In Orthodoxy, which positions itself as a keeper of traditions, the family is a small church, where the husband serves as an intermediary between God and other family members, a conductor of divine grace, while the wife occupies a subordinate position, which is enshrined in the rite of wedding. Children should obey to their parents, who are responsible for their physical and spiritual development (Rozhdestvensky, 1994; Troitsky, 2001). Religious attitudes concerning the family are enshrined in the prototext of the Gospel (it the first miracle created by Jesus Christ occurred during the marriage feast) and the texts of Holy Tradition, the teachings of St. church fathers, lives of the saints, sermons of the clergy. Such religious attitudes can be considered axiological ideals. The axiological ideal is in a dichotomous relationship with the concept of axiological reality. We believe that the axiological reality is reflected in marriage announcements, which have been studied by Russian and foreign linguists (Kolodziejczyk, 2006; Orszulak-Dudkowska, 2008; Rykova, 2017; Ryseva, 2014; Sobstyl, 2016; Vepreva, 2018; Vepreva \& Pazio-Vlazlovskaya, 2018, 2019; Wojtak, 1990; Xu, 2016).

\section{Problem Statement}

Texts of marriage announcements posted on Orthodox-oriented dating sites reflect an axiological reality, which is understood as an assimilated, internalized system of value orientations guided people creating families. The Internet space characterized by freedom of expression in conjunction with the basic human need - to create a family - leads to the explication of real value ideas about the family.

\section{Research Questions}

The genre of marriage announcements functions in secular and religious environments. Marriage ads contain verbalized values that reflect an axiological reality.

1. What values do men convey in marriage ads?

2. What values do women convey in marriage ads?

3. To what extent do the attitudes explicated in ad texts coincide with axiological ideals?

\section{Purpose of the Study}

The purpose of this study is to identify family values in marriage ads. Texts of marriage announcements reflect an axiological reality: by indicating the desired traits of a partner and / or selfidentification, the authors explicate value attitudes that reflect their ideas about an ideal life partner. The 
goal is achieved through the following tasks: selection of texts, linguoaxiological and linguoculturological analysis of marriage announcements, identification of signs of axiological reality in the family sphere.

\section{Research Methods}

The work uses the methods of a linguoaxiological analysis aimed at identifying value attitudes of the individual; a linguocultural analysis contributing to the description of basic values of Russian culture; interpretation of ways to represent key values in marriage announcements.

\section{Findings}

The research material is texts of marriage announcements posted on Orthodox dating sites.

Orthodox Christianity.ru is a directory of Orthodox Internet resources http://www.hristianstvo.ru/life/family/marriage/2/ - accessed 01.05.2019 - describes a picture of Orthodox sites dedicated to starting a family and posting dating ads. The catalog includes 15 sites dedicated to creating a family and including a dating section: Nadezhda. Ukrainian Orthodox dating site; The light. Dating club for Orthodox Christians; The ABC of Fidelity. Dating service; Towel. Orthodox dating; Gull. Orthodox dating service; Orthodox dating. Orthodox social network; Parishioners. Dating and communication site; Destined. Network for communication and dating of Orthodox Christians; Scarlet Sails. Orthodox dating site; Orthodox dating; Real love; Gull. Orthodox Youth Club, St. Petersburg; Christian.Ru. Orthodox Women's Forum; Dating for Orthodox Christians, Kaluga; Acquaintance under the church dome. Orthodox social network. The main body of the texts was taken from the Svetelka website.

The ads represent both spiritual and pragmatic values. Men declare seriousness of their intentions: they indicate a desire to start a family, enter into serious relationships, which meet the objectives of an Orthodox dating site. In Russia, civil marriages are widespread. 37\% of those wishing to start a family have traditional family values.

Faith in God (25\%) is indicated as a value: an Orthodox woman is needed; a girl who observes fasting and leads a Christian lifestyle; churched; Orthodox half; regularly visiting the temple. The term "churched" is specified: participating in the Sacraments; regularly visiting the temple. Men are ready to see the bride who is ready to develop spiritually, intellectually and physically; a believer. There are few announcements where men show indifference to the faith of a partner. It can be assumed that the placement of a dating advertisement presupposes a religious audience, which explains silence about faith in most of the ads.

$25 \%$ of ads explicate such values as kindness and loyalty: kind; friendly; able to build clean, good relationships; kindness; the basis of fidelity is chastity, honesty, trust.

Only a few advertisements contained such a family value as live, especially love for the rest of life: with whom you can meet old age in love and peace.

Grooms do not want mercantile wives: I ask not to bother mercantile women!.

A statistical analysis has shown that the desire to start a family and the geographic factor rank first (37\% of authors); the place of residence plays an important role: I will meet a girl only from Moscow, 
this is mandatory; from Moscow, St. Petersburg or other regions; preferably from the same region. Pragmatic considerations come to the fore. Grooms are not ready to move and require brides to move: she must agree to move. The single phrase I am looking for a girl not from Moscow, presumably, reflects a widespread stereotype about the spoiled, demanding metropolitan residents.

The age is important for men (16\%), the reference point is $+/-5$ years younger; the age limit is indicated: up to 35 years, up to 45 years. Men indicate age parameters: not older than 42 and not younger than 20 years old.

$16 \%$ of the authors mention beauty and decency. External beauty: pretty, sweet, beautiful, appearance matters. Spiritual beauty is needed. A girl should not have bad habits, lead an adequate lifestyle.

The attitude of men to the mind is indicative, reflecting patriarchal views: not stupid (very smart), not stupid (not very smart).

In most advertisements, grooms want to see a bride without sexual experience and children: unmarried, without children; no intimate experience.

An ideal idea is formulated: I would like to meet a lonely, modest and shy girl who is waiting for her beloved and dreams of having a strong family and children; I really appreciate inner, spiritual beauty. It is very important to value time. The purpose of acquaintance is family, birth and education of children!

The image of an author of the ads is also indicative. By identifying themselves, men formulate value preferences. Men position themselves as believers: I work in monasteries; Orthodox, but I rarely go to church; I try to go to the Temple and participate in the Sacraments of the Church; I take part in pilgrimage trips every year; I have an initial spiritual education; I am not a church member, but I prefer to live in accordance with the Commandments of the Lord, and I try to do this not formally.

Education, specialty, and position are also important: I have a higher education, I am an engineer by profession; I am a brigade head, I work for a large domestic company; I am a military pensioner; I have stable work in the field of information technology; I worked in various fields.

Demanding purity and chastity, men indicate that they have never been married, have no children.

The authors believe that their broad outlook, versatile hobbies make them attractive: I love Russian classics and spiritual literature; I am interested in science, technology, history; I love opera, instrumental, classical and Soviet music, popular science magazines, old color films (1940-1960), historical films, newsreels. I am fond of photography, traveling around Russia, I love walks in picturesque places, nature, beautiful architecture; I try to lead a healthy lifestyle, to learn something. In my free time I am engaged in cycling, picking mushrooms, plants, restoration, etc .; I love a secluded lifestyle and nature. I don't like the hustle and bustle.

Male ads reflect an axiological reality, which is characterized by universal human values: I would like to meet a person who agrees to move to my place, for whom family is a value. I would like to find a woman for whom decency, honesty, trust, support are not just words. For me, mutual understanding is very important. To be together because $1+1$ is not 2, but much more. Go through life together, grow, develop, experience different situations, be one, make each other happier day after day. 
The generalized author is very responsible, reliable, serious, calm; more homey, kind, caring and attentive; prefers relationships without quarrels.

One announcement can serve as an example: A young man with an academic degree, Orthodox will meet a chaste Muscovite aged 19-28 in order to create a pious Orthodox family.

When comparing the texts of male ads with the female texts, we observed that the latter also pay attention to the religion: an Orthodox believer is needed; I will get acquainted with an Orthodox Christian; I will meet an Orthodox young man; I would like to see my future husband deeper into the Church than mine; I want to travel together to Holy places, sometimes to work in monasteries for the Glory of God; I will meet an Orthodox young man from Moscow who regularly receives Communion; I will be glad to meet a person who strives to live according to the commandments of God; MEETING FOR CREATING A SMALL CHURCH. Women indicate their own attitude to faith: I graduated from the Orthodox Institute, but I am from an atheistic family, so I am gradually becoming a churchgoer; Orthodox, sincere, with a specific sense of humor.

The female authors emphasize their innocence, absence of children: I have never been married, have no children; the same is demanded from the partner: have never been married and without children; free, without children. They have a negative attitude towards cohabitation: I react negatively to offers to live in cohabitation.

If men pay attention to the place of residence, women focus on nationality, territorial affiliation: $I$ want to find a Russian guy from Moscow or Moscow region; I will get acquainted with RUSSIAN !; My ideal is a Russian guy from Moscow; only Russian.

Like men, women emphasize their own versatile interests: I love nature, tinkering in the country, going to museums, walking around the center of Moscow, pilgrimage trips; I love nature, romance, sunsets and sunrises. I ride a bike, I like walking, swimming. I used to read a lot of classical literature. I love Russian rock, folk songs, classical works, art, movies, museums, exhibitions, etc. I love musicals and puppet shows.

Women are pragmatic; real communication is important: I will meet a good-natured person. Ready for real communication.

The ideal of family life is the following romantic picture: I want a miracle on Christmas, go to Sunday services together, bake charlotte in quiet family evenings, pick up mushrooms and berries in summer, and make jam in autumn evenings.

\section{Conclusion}

Thus, the texts of Orthodox marriage announcements reflect the axiological reality of family relations, which is based on axiological ideals: faith in God, decency, chastity, innocence, kindness, lack of mercantile interests. The Soviet ideas about family have been preserved. The pragmatically determined requirements for the place of residence and nationality indicate the need to take into account cultural and economic characteristics of Russia: large territories and diversity of nationalities. 


\section{Acknowledgments}

The research was financially supported by the Russian Fund for Fundamental Research within the scientific project No. 18-012-00382 A "Speech life of the family: axiological reality and research methods (based on the Ural city speech)"

The study was supported by Program 211 of the Government of the Russian Federation, Agreement No. 02.A03.21.0006 supported by Act 211 of the Government of the Russian Federation, agreement No. 02.A03.21.0006.

\section{References}

Kolodziejczyk, A. (2006). Wspolczesna Ieksyka na uslugach autoprezentacji (cechy fizyczne na podstawie analizy internetowych anonsow towarzysko-matrymonialnych) [Contemporary dictionaries on self-presentation services (physical features based on the analysis of online social and matrimonial advertisements)]. Poradnik Jazykowy, 3, 52-66.

Orszulak-Dudkowska, K. (2008). Ogloszenia matrymonialne. Studium z pogranicza folklorystyki $i$ antropologii kultury [Dating Ads. A study on the border of folklore and cultural anthropology]. Polskie Towarzystwo Ludoznawcze.

Rozhdestvensky, A. V. (1994). Sem ya pravoslavnogo xristianina [The seed of an Orthodox Christian]. Parovaya tipografiya N.V. Gaevskogo.

Rykova, O. A. (2017). Kommunikativno-pragmaticheskoe soderzhanie rechevogo zhanra "brachnoe ob "yavlenie" [Communicative and pragmatic content of the speech genre "marriage declaration"]. Perevod i mezhkul turnaya kommunikaciya: teoriya i praktika, 3, 31-36.

Ryseva, U. A. (2014). Brachny`e ob“yavleniya nachala XXI v. i ix lingvostilisticheskie osobennosti [Marriage declarations of the beginning of the XXI v. i ix and their linguistic and stylistic features]. Vest. Vyatskogo gosudarstv. Gumanitar. Univer., 11, 55-59.

Sobstyl, K. (2016). Przelamywanie tabu w ogloszeniach towarzysko-matrymonialnych. Tabu w procesie globalizacji kultury [Breaking taboos in social and matrimonial advertisements. Taboo in the process of culture globalization]. Wydawnictwo Uniwersytetu Marii Curie-Sklodowskiej.

Troitsky, S. V. (2001). Hristianskaya filosofiya braka [Christian philosophy of marriage]. Fond "Hristianskaya zhizn'”.

Vepreva, I. T. (2018). Innovacionny`e metody` issledovaniya aksiologicheskogo soderzhaniya rechevogo by ta sem'I [Innovative methods for studying the axiological content of speech output by a family]. Cross - Cultural Stud.: Ed. and Sci., 3, 107-113.

Vepreva, I. T., Iczkovich, M. M., Kupina, N. A., \& Shalina, I. V. (2016). Cennostny`e predpochteniya sovremennoj studencheskoj molodezhi v lingvokognitivnom i sociopsixologicheskom osveshhenii [Value preferences of modern student youth in linguo-cognitive and sociopsychological coverage]. Voprosy kognitivnoj lingvistiki, 2, 62-73.

Vepreva, I. T., Kupina, N. A., \& Iczkovich, T. V. (2018). Bazovy`e cennosti i ix otrazhenie v rechevom prostranstve ural'skogo goroda [Basic values and their reflection in the speech space of the Uralyosky city]. Vest. Rossijskogo fonda fund. issled. Guman.i obshhestv. Nauki, 3(92), 97-106.

Vepreva, I. T., \& Pazio-Vlazlovskaya, D. (2018). Chto mogut soobshhit’ brachny`e ob“yavleniya o sovremennoj zhenshhine (na materiale pol`skogo i russkogo yazy'kov) [What can a marriage announcement tell about a modern woman (based on the material of Poleskoye and Russian)]. Rusin, 52(2), 177-192.

Vepreva, I. T., \& Pazio-Vlazlovskaya, D. (2019). O proyavlenii gegemonnoj maskulinnosti sovremenny`x muzhchin $\mathrm{v}$ tekste brachnogo ob "yavleniya (na materiale pol'sokgo i russkogo yazy`kov) [On the manifestation of the hegemonic masculinity of modern men in the text of the marriage declaration (based on the material of Polysokgo and Russian languages)]. Vest. Tomskogo univer. Filolog., 62, 54-68. 
Wojtak, M. (1990). Z problematyki opisu stylu tekstow uzytkowych na podstawie analizy ogloszen matrymonialnych. Poradnik Jazykowy [From the problem of describing the style of utility texts on the basis of the analysis of matrimonial advertisements. Jazykowy guidebook]. Organ Towarzystwa Kultury Jazyka, 2, 79-87.

$\mathrm{Xu}$, S. (2016). Verbal’ny`e znaki cennostny`x predpochtenij sovremennoj zhenshhiny` (na materiale brachny'x ob "yavlenij) [Verbal signs of the value preferences of a modern woman (based on marriage declarations)]. Nauchny $j$ dialog, 11(59), 110-120 p. 